\title{
COMPARISON OF METHODS FOR MYCOBACTERIA ISOLATION FROM SWINE FECES
}

\author{
Eugenia Márcia de Deus Oliveira ${ }^{1 *}$; César Alejandro Rosales Rodriguez²;Vivianne Cambuí Mesquita Rocha²; \\ Simone Rodriguez Ambrosio ${ }^{2}$; Patrícia Miyuki Ohara²; Marcos Amaku²; Fernando Ferreira² ${ }^{2}$; Ricardo Augusto Dias²; \\ Sylvia Cardoso Leão ${ }^{3}$; José Soares Ferreira Neto
}

${ }^{1}$ Departamento de Medicina Veterinária Preventiva, Escola de Medicina Veterinária, Universidade Federal da Bahia, Salvador, BA, Brasil; ' 2 epartamento de Medicina Veterinária Preventiva e Saúde Animal, Faculdade de Medicina Veterinária e Zootecnia, Universidade de São Paulo, São Paulo, SP, Brasil; ${ }^{3}$ Departamento de Microbiologia, Escola Paulista de Medicina, Universidade Federal de São Paulo, São Paulo, SP, Brasil

Submitted: March 26, 2007; Returned to authors for corrections: April 20, 2007; Approved: September 28, 2007

\begin{abstract}
Swine mycobacteriosis is an important cause of carcass condemnation at abattoirs. One of the best ways to recognize the etiologic agent involved, in live animals, is the fecal isolation, as $94 \%$ of the lesions are located in the digestive tract. Therefore, the goal of the present study was to compare the performance of four decontamination methods followed by inoculation in three different culture media, totalizing twelve procedures of mycobacteria search from swine fecal samples experimentally contaminated. The swine feces were artificially contaminated with $0.02 \mathrm{~g}$ of Mycobacterium avium, PIG-B strain, and subjected to mycobacteria isolation trial. The protocols used were: 1) modified Petroff or basic method; 2) modified Lowenstein-Jensen or acidic method; 3) modified Petroff or basic method with re-suspension in Amphotericin B; 4) modified LowensteinJensen or acid method with re-suspension in Amphotericin B, followed by inoculation in Petragnani, Lowenstein-Jensen and Lowenstein-Jensen medium with antibiotics (Penicillin $G$ and Nalidixic acid). There was a difference $(p<0.05)$ between the mycobacterial recovery percentages from swine feces. The acid method with re-suspension in Amphotericin B solution and inoculation in Lowenstein-Jensen medium with antibiotics showed the best results ( $87 \%$ of mycobacteria recovery).
\end{abstract}

Key words: Mycobacterium avium, isolation, feces, swine

\section{INTRODUCTION}

Mycobaterium avium infection in swines has been observed in a number of countries - including Brazil - where domestic animals are raised in modern production systems. The importance of this infection has increased in recent years due to the raising number of observed lesions in slaughtered animals, generating economic loss by carcasses condemnations $(1,8,14)$. The infection is also a potential hazard to public health (19) although all possible inter-relations between agent, host and environment are not yet known. It is impossible to macroscopically differentiate lesions caused by the Mycobacterium avium complex (MAC) from those caused by M. bovis or M. tuberculosis. Only the direct diagnosis methods allow to establishing the diagnosis of an infection caused by the Mycobacterium avium complex in live swines. It is difficult to use an indirect and efficient test to support epidemiological studies and control strategies in rural areas (13).

Since granulomatous lymphadenitis in swines are located in the digestive tract in $94 \%$ of the cases (10), isolation from the feces constitutes the best possibility of diagnosis in the live animal. Furthermore, it allows one to identify the agent involved with the infection.

The isolation of mycobacteria in the laboratory constitutes a problem on its own. Mycobacteria require relatively long replication times when compared to those of other types of bacteria that might be present in the same sample. This imbalance in the growth speed can result in metabolic acids accumulation

*Corresponding Author. Mailing adress: Rua Prof. Cassilandro Barbuda, n. 966, Edf. São Judas Tadeu, apt. 102. Costa Azul. Salvador- Bahia. CEP: 41760-110. E-mail: emdo@ufba.br, emdo@usp.br. Tel.: (71) 3263-6742. 
and consequently leads the culture to liquefy, causing unsatisfactory isolation of the mycobacteria. For this reason, the success in isolating mycobacteria depends on the selective supervision of contaminating bacteria. The high lipid levels of the cell membrane of most mycobacteria make them more resistant, when compared to non-spored bacteria, to strong acidic and alkaline solutions alike (11). These characteristics can be explored in the attempt to its isolation, allowing the samples to be decontaminated. In fact, it has been shown that mycobacteria can be isolated from a number of samples considered either nonsterile or contaminated such as tracheal mucus, necropsy material, purulent secretions and feces to name but a few (3).

A large number of different solutions have been used in combination with different concentrations of chemical substances aiming the inactivation of the accompanying microbiota while trying to minimize the injury to the mycobacteria. From the literature in this field, we can cite decontamination using oxalic acid (12) and hexadecylpyridinium chloride (6). Protocols using lauril sodium sulphate, trisodium phosphate and monosodium phosphate (modified Corper and Stoner method), N-acetyl-L-cisteina- sodium hydroxide (Kubica and Dye method), cetyl-peridinic chloride (CCP method) sulphuric acid (Lowenstein-Jensen method) and sodium hydroxide (modified Petroff method) have been reported $(4,5,7,9,15)$.

The aim of the present study is to compare different isolation methods of mycobacteria from the samples of swine feces and to determine which method shows the best association between viability and capacity of multiplication of mycobacteria while avoids the growth of the accompanying microbiota.

\section{MATERIALS AND METHODS}

In order to enhance the isolation method of mycobacteria from swine feces, thirty repetitions of each different protocol were used.

\section{Experimental Design}

Thirty swine, from a herd with no tuberculosis condemnation at the slaughterhouse for the last year and negative cultures of micobacteria from feces (3) were selected to the experiment.

The PIG-B strain samples of Mycobacterium avium were isolated from swine of Southern Brazil. Out of the four families of $M$. avium characterised by the RFLP technique (18), this strain presented the largest capabilities for multiplication in hamster tissue (14).

About $2.0 \mathrm{~g}$ of fresh feces from these thirty different swine were collected. One gram of each sample of experimentally contaminated feces with $0.02 \mathrm{~g}\left(10^{8} \mathrm{U}\right.$.F.C. $)$ of PIG-B strain of Mycobacterium avium was homogenized with $9 \mathrm{~mL}$ of $\mathrm{NaCl}$ $0.85 \%$ solution. This suspension was then filtered and left to rest for 10 minutes. Subsequently $1 \mathrm{~mL}$ sub sample of supernatant was submitted to attempts of mycobateria isolation, using the following decontamination protocols: 1) modified Petroff or basic method (15); 2) modified Lowenstein-Jensen or acidic method (16); 3) modified Petroff or basic method with resuspension in Amphotericin B; 4) modified Lowenstein-Jensen or acid method with re-suspension in Amphotericin B, followed by double inoculation in Petragnani, Lowenstein-Jensen and Lowenstein-Jensen with antibiotics (Penicillin G and Nalidixic acid) culture media.

For the basic method, $1 \mathrm{~mL}$ of $\mathrm{NaOH}$ at $4 \%$ and two drops of phenol red were added to the sample which was shaken and subsequently incubated at $37^{\circ} \mathrm{C}$ for 20 minutes. After this period, a solution of hydrochloric acid at $1 \mathrm{~N}$ was added to the sample until a change of color was noted from red to brown and the $\mathrm{pH}$ was stabilized between 6.5 and 7.0.

The acid method was carried out by adding $1 \mathrm{~mL}$ of $\mathrm{H}_{2} \mathrm{SO}_{4}$ at $12 \%$ and two drops of phenol red to the sample. It was also shaken and incubated at $37^{\circ} \mathrm{C}$ for 20 minutes. After this period, a sodium hydroxide solution at $4 \%$ was continuously added until the color of the solution changed from yellow to brown and the $\mathrm{pH}$ was stabilized at values between 6.5 and 7.0.

From then, all samples were submitted to the follow sequence of steps: 1) $1000 \mathrm{G}$ centrifuging for 20 minutes; 2) removal of supernatant; 3 ) re-suspension of sediments with $2.0 \mathrm{~mL}$ of a sterile saline solution and with $2.0 \mathrm{~mL}$ of amphotericin B (250 micro grams $/ \mathrm{mL}$ ); 4) homogenization of the suspension followed by inoculating of 100 micro liters for each of the tubes containing Petragnani medium, Lowenstein-Jensen and Lowenstein-Jensen

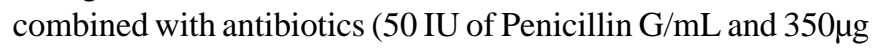
of nalidixic acid $/ \mathrm{mL}$ ). This last procedure was performed in duplicate. So, the 12 groups were:

AP: Basic method with re-suspension in sterile saline solution and inoculation in Petragnani medium;

AL: Basic method with re-suspension in sterile saline solution and inoculation in Lowenstein-Jensen medium;

AA: Basic method with re-suspension in sterile saline solution and inoculation in Lowenstein-Jensen medium with antibiotics;

BP: Acidic method with re-suspension in sterile saline solution and inoculation in Petragnani medium;

BL: Acidic method with re-suspension in sterile saline solution and inoculation in Lowenstein-Jensen medium;

BA: Acidic method with re-suspension in sterile saline solution and inoculation in Lowenstein-Jensen medium with antibiotics;

CP: Basic method with re-suspension in Amphotericin B solution and inoculation in Petragnani medium;

CL: Basic method with re-suspension in Amphotericin B solution and inoculation in Lowenstein-Jensen medium;

CA: Basic method with re-suspension in Amphotericin B solution and inoculation in Lowenstein-Jensen medium with antibiotics; 
DP: Acidic method with re-suspension in Amphotericin B solution and inoculation in Petragnani medium;

DL: Acidic method with re-suspension in Amphotericin B solution and inoculation in Lowenstein-Jensen medium;

DA: Acidic method with re-suspension in Amphotericin B solution and inoculation in Lowenstein-Jensen medium with antibiotics.

All the 30 feces samples had been decontaminated by the method of Petroff, before being artificially contaminated with strain PIG-B of M. avium, for the control of a possible previous contamination .

From the 30 feces samples, 100 micro liters were inoculated in the same three pairs of culture media, but without any decontamination procedure (control).

The tubes were then placed at an incubator at $37^{\circ} \mathrm{C}$ and examined every day for the first week and each seven days until four weeks of incubation, when it was observed the recovery of mycobacteria (yes or no) and the presence of contamination.

\section{Statistical Treatment}

The proportion of agent recovery was compared by the test of two proportions, through the statistical program Minitab 14 (Minitab Inc, 2003). The following criteria was adopted when performing the calculations for the proportion of recovery ((30contaminated)/30): since each sample was inoculated in a pair of tubes, the sample was considered contaminated every time at least one of the tubes was contaminated.

To choose the best protocol, the tests were made between all 12 ( 2 by 2 ). To compare the Petragnani and the Lowenstein Jensen media, the consolidate results of the AP, BP, CP and DP protocols were compared with the AL, BL, CL and DL ones. To verify if the re-suspension with amphotericin B solution improves the recovery rate of $M$. avium, the consolidate results of the $\mathrm{AP}, \mathrm{AL}$, $\mathrm{AA}, \mathrm{BP}, \mathrm{BL}$ and $\mathrm{BA}$ protocols were compared with the $\mathrm{CP}, \mathrm{CL}$, CA, DP, DL and DA ones. To verify if the antibiotics added to the Lowenstein Jensen medium improves the recovery rate of M. avium, the consolidate results of the $\mathrm{AL}, \mathrm{BL}, \mathrm{CL}$ and $\mathrm{DL}$ protocols were compared with the AA, BA, CA and DA ones.

\section{RESULTS}

In none of the thirty feces samples decontaminated for the method of Petroff, before being artificially contaminated with strain PIG-B of M. avium, it was isolated suggestive colonies of mycobacteria.

Feces samples which did not undergo any decontamination protocol (control), were contaminated within 4 days of incubation. All the samples where M. avium was isolated showed confluent growth of colonies in all three culture media.

Tables 1, 2 and Fig. 1 show the obtained results. The Table 1 results allow to elaborate the following success scale in the
Table 1. Percentage of recovery and the percentage of contamination for 12 protocols of $M$. avium isolation from swine feces.

\begin{tabular}{cccccc}
\hline methods & $\begin{array}{c}\text { examined } \\
\text { samples }\end{array}$ & $\begin{array}{c}\text { recovery of } \\
\text { M.avium }\end{array}$ & $\begin{array}{c}\text { contami- } \\
\text { nation }\end{array}$ & $\%$ \\
\hline AP & 30 & 14 & 46.7 & 16 & 53.3 \\
AL & 30 & 9 & 30.0 & 21 & 70.0 \\
AA & 30 & 21 & 70.0 & 90 & 30.0 \\
BP & 30 & 16 & 53.3 & 14 & 46.7 \\
BL & 30 & 18 & 60.0 & 12 & 40.0 \\
BA & 30 & 24 & 80.0 & 6 & 20.0 \\
CP & 30 & 11 & 36.7 & 19 & 63.3 \\
C & 30 & 8 & 26.7 & 22 & 73.3 \\
CA & 30 & 14 & 46.7 & 16 & 53.3 \\
DP & 30 & 19 & 63.3 & 11 & 36.7 \\
DL & 30 & 24 & 80.0 & 6 & 20.0 \\
DA & 30 & 26 & 86.7 & 4 & 13.3 \\
\hline
\end{tabular}

Legend:

AP: Basic method with re-suspension in sterile saline solution 0,85\% and inoculation in Petragnani medium;

AL: Basic method with re-suspension in sterile saline solution 0,85\% and inoculation in Lowenstein-Jensen medium;

AA: Basic method with re-suspension in sterile saline solution $0.85 \%$ and inoculation in Lowenstein-Jensen medium with antibiotics;

BP: Acidic method with re-suspension in sterile saline solution $0.85 \%$ and inoculation in Petragnani medium;

BL: Acidic method with re-suspension in sterile saline solution 0.85\% and inoculation in Lowenstein-Jensen medium;

BA: Acidic method with re-suspension in sterile saline solution $0.85 \%$ and inoculation in Lowenstein-Jensen medium with antibiotics;

CP: Basic method with re-suspension in Amphotericin B solution and inoculation in Petragnani medium;

CL: Basic method with re-suspension in Amphotericin B solution and inoculation in Lowenstein-Jensen medium;

CA: Basic method with re-suspension in Amphotericin B solution and inoculation in Lowenstein-Jensen medium with antibiotics;

DP: Acidic method with re-suspension in Amphotericin B solution and inoculation in Petragnani medium;

DL: Acidic method with re-suspension in Amphotericin B solution and inoculation in Lowenstein-Jensen medium;

DA: Acidic method with re-suspension in Amphotericin B solution and inoculation in Lowenstein-Jensen medium with antibiotics.

percentage of recovery against $M$. avium: $86.7 \%$ (DA protocol), 80\% (DL and BA protocols), 70\% (AA protocol), 63.3\% (DP protocol), 60\% (BL protocol), 53.3\% (BP protocol), 46.7\% (AP and CA protocols), $36.7 \%$ (CP protocol), 30\% (AL protocol) and $26.7 \%$ (CL protocol) ( $<<0.05$, Fig. 1, Table 2).

The worst protocol for this set of experiments was the basic method with re-suspension in amphotericin B solution and inoculation in a Lowenstein-Jensen medium whereas the best 
was the acid method with re-suspension in an amphotericin B solution and inoculation in a Lowestein-Jensen medium with antibiotics ( $\mathrm{p}<0.001$, Table 2$)$.

It was not observed statistical differences between the recovery rates of the Petragnani (60/120, Table 1$)$ and the Lowenstein Jensen media $(59 / 120$, Table 1$)(p=0.9)$. The resuspension with amphotericin B solution did not improve the recovery rate of M. avium $(102 / 180 \times 102 / 180$, Table 1$)(\mathrm{p}=1)$. The

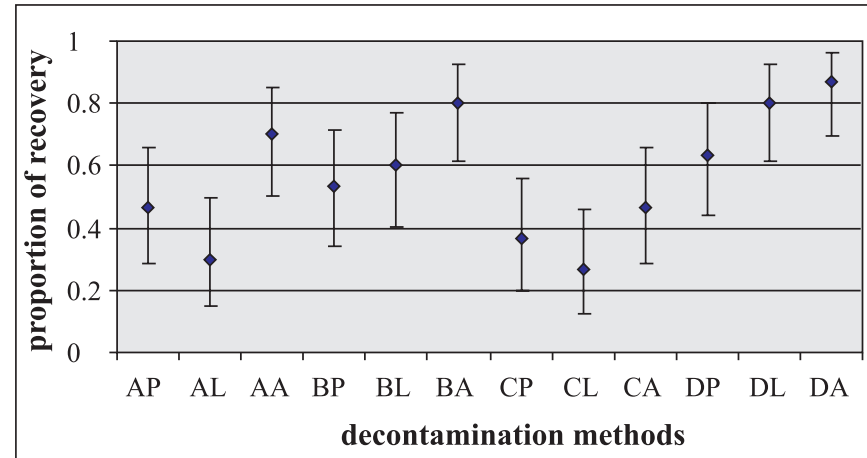

Legend:

AP: Basic method with re-suspension in sterile saline solution $0,85 \%$ and inoculation in Petragnani medium;

AL: Basic method with re-suspension in sterile saline solution $0,85 \%$ and inoculation in Lowenstein-Jensen medium;

AA: Basic method with re-suspension in sterile saline solution $0,85 \%$ and inoculation in Lowenstein-Jensen medium with antibiotics;

BP: Acidic method with re-suspension in sterile saline solution $0,85 \%$ and inoculation in Petragnani medium;

BL: Acidic method with re-suspension in sterile saline solution $0,85 \%$ and inoculation in Lowenstein-Jensen medium;

BA: Acidic method with re-suspension in sterile saline solution $0,85 \%$ and inoculation in Lowenstein-Jensen medium with antibiotics;

CP: Basic method with re-suspension in Amphotericin B solution and inoculation in Petragnani medium;

CL: Basic method with re-suspension in Amphotericin B solution and inoculation in Lowenstein-Jensen medium;

CA: Basic method with re-suspension in Amphotericin B solution and inoculation in Lowenstein-Jensen medium with antibiotics;

DP: Acidic method with re-suspension in Amphotericin B solution and inoculation in Petragnani medium;

DL: Acidic method with re-suspension in Amphotericin B solution and inoculation in Lowenstein-Jensen medium;

DA: Acidic method with re-suspension in Amphotericin B solution and inoculation in Lowenstein-Jensen medium with antibiotics.

Figure 1. Recovery proportion of $M$. avium from swine feces observed in 12 protocols of isolation, and $95 \%$ confidence intervals (bars). antibiotics added to the Lowenstein Jensen medium improved the recovery rate of M. avium (59/120 x 85/120, Table 1) ( $p<0.001)$.

\section{DISCUSSION}

The contamination verified in all control samples confirms that a decontamination method is essential in isolating mycobacteria from swine feces. It also suggests that the level of contaminants in the samples was very high.

The confluent growth of $M$. avium colonies, in all three culture media, suggests that the addition of antibiotics in the Lowenstein-Jensen did not significantly interfere with the growth of the agent.

The worst isolation protocol was the basic method with resuspension in amphotericin B solution and inoculation in a Lowestein-Jensen medium (recovery rate $=26.7 \%$, Table 1 ).

Although the statistical analysis showed that the DA protocol did not recovered more mycobacteria than protocols AA, BA and DL (Table 2), the raw data show a larger percentage of recovery for former protocol $(86.7 \%$, Table 1$)$.

Balian et al. (3) compared two decontamination methods for hamster feces experimentally infected with M. avium - Petroff method $(\mathrm{NaOH}$ at $4 \%)$ and modified Lowestein-Jensen method $\left(\mathrm{H}_{2} \mathrm{SO}_{4}\right.$ at $\left.4 \%\right)$. Although they observed a moderate agreement between the two methods, they were also successful in isolating $32 \%$ and $29 \%$ of mycobacteria, respectively. The authors suggest that larger concentrations of $\mathrm{H}_{2} \mathrm{SO}_{4}$ might reduce the frequency of contamination and, consequently, increase the success rate of isolation. In the present study the $\mathrm{H}_{2} \mathrm{SO}_{4}$ (acid method) concentration was $12 \%$, three times larger than the used by Balian et al. (3). The Table 1 results show recovery rates varying from $53.3 \%$ to $86.7 \%$ for the protocols with acid method of decontamination.

Silva et al. (17) used two different decontamination methods for swine feces experimentally contaminated by MAC - NaOH at $4 \%$ and oxalic acid at $5 \%$. The authors noticed that their attempts to isolate mycobacteria from feces were unsatisfactory, since there was a high level of contamination of the media by fungi and bacteria for both methods. Based on these results obtained for the $\mathrm{NaOH}$ at $4 \%$, it was decided, in the present study, to include two variations on the decontamination methods tested by those authors: addition of antibiotics in the Lowestein-Jensen medium and substitution of the saline solution used in the sediment re-suspension process by a solution containing anti-micotic (amphotericin B). The results show that only the antibiotics added to the Lowenstein Jensen medium statistically improve the recovery rate of M. avium.

As a result of this work, the best procedure obtained, i. e., the one that allowed for the largest success rate for isolation (86.7\%, DA method, Table 1), was decontamination with $\mathrm{H}_{2} \mathrm{SO}_{4}$ at $12 \%$ followed by re-suspension with anti-micotic and inoculating in a Lowestein-Jensen medium with antibiotics. 
Table 2. P values resulting from the comparison between the recovery proportion of M. avium from swine feces observed in 12 protocols of isolation.

\begin{tabular}{|c|c|c|c|c|c|c|c|c|c|c|c|}
\hline & $\mathbf{A P}$ & $\mathbf{A L}$ & $\mathbf{A A}$ & BP & BL & BA & CP & CL & CA & DP & DL \\
\hline $\mathbf{A P}$ & & & & & & & & & & & \\
\hline $\mathbf{A} \mathbf{L}$ & 0.18 & & & & & & & & & & \\
\hline $\mathbf{A A}$ & 0.07 & 0.002 & & & & & & & & & \\
\hline BP & 0.61 & 0.067 & 0.18 & & & & & & & & \\
\hline BL & 0.3 & 0.02 & 0.42 & 0.6 & & & & & & & \\
\hline BA & 0.01 & $<0.001$ & 0.37 & 0.03 & 0.09 & & & & & & \\
\hline CP & 0.43 & 0.584 & 0.01 & 0.19 & 0.07 & $<0.001$ & & & & & \\
\hline CL & 0.11 & 0.774 & $<0.001$ & 0.04 & 0.01 & $<0.001$ & 0.405 & & & & \\
\hline CA & 1 & 0.184 & 0.07 & 0.61 & 0.3 & 0.007 & 0.432 & 0.108 & & & \\
\hline DP & 0.19 & 0.01 & 0.58 & 0.43 & 0.79 & 0.152 & 0.039 & 0.004 & 0.19 & & \\
\hline DL & 0.01 & $<0.001$ & 0.37 & 0.03 & 0.09 & 1 & $<0.001$ & $<0.001$ & 0.01 & 0.15 & \\
\hline DA & $<0.001$ & $<0.001$ & 0.12 & 0.01 & 0.02 & 0.488 & $<0.001$ & $<0.001$ & $<0.001$ & 0.04 & 0.49 \\
\hline
\end{tabular}

Legend:

AP: Basic method with re-suspension in sterile saline solution $0.85 \%$ and inoculation in Petragnani medium;

AL: Basic method with re-suspension in sterile saline solution $0.85 \%$ and inoculation in Lowenstein-Jensen medium;

AA: Basic method with re-suspension in sterile saline solution $0.85 \%$ and inoculation in Lowenstein-Jensen medium with antibiotics;

BP: Acidic method with re-suspension in sterile saline solution $0.85 \%$ and inoculation in Petragnani medium;

BL: Acidic method with re-suspension in sterile saline solution $0.85 \%$ and inoculation in Lowenstein-Jensen medium;

BA: Acidic method with re-suspension in sterile saline solution $0.85 \%$ and inoculation in Lowenstein-Jensen medium with antibiotics;

CP: Basic method with re-suspension in Amphotericin B solution and inoculation in Petragnani medium;

CL: Basic method with re-suspension in Amphotericin B solution and inoculation in Lowenstein-Jensen medium;

CA: Basic method with re-suspension in Amphotericin B solution and inoculation in Lowenstein-Jensen medium with antibiotics;

DP: Acidic method with re-suspension in Amphotericin B solution and inoculation in Petragnani medium;

DL: Acidic method with re-suspension in Amphotericin B solution and inoculation in Lowenstein-Jensen medium;

DA: Acidic method with re-suspension in Amphotericin B solution and inoculation in Lowenstein-Jensen medium with antibiotics.

\section{RESUMO}

\section{Comparação de métodos para isolamento de micobactérias a partir de fezes suínas}

As micobacterioses suínas são responsáveis por condenações de carcaças em abatedouro e uma das melhores formas de se conhecer os agentes envolvidos nos animais vivos é o isolamento a partir das fezes, pois em $94 \%$ das vezes, as lesões localizam-se no trato digestivo. Assim sendo, o presente estudo teve por objetivo comparar o desempenho de quatro métodos de descontaminação com semeadura em três diferentes meios de cultura, totalizando doze procedimentos na pesquisa de micobactérias a partir de amostras de fezes de suínos contaminadas experimentalmente. Amostras de fezes de suínos foram contaminadas artificialmente com 0,02g de Mycobacterium avium, estirpe de PIG-B, e submetidas à tentativa de isolamento de micobactérias, utilizando-se os seguintes protocolos de descontaminação: 1) Petroff modificado ou método básico; 2) Lowenstein-Jensen modificado ou método ácido; 3) Petroff modificado ou método básico e ressuspensão com anfotericina
B; 4) Lowenstein-Jensen modificado ou método ácido e ressuspensão com anfotericina $B$; com subseqüente semeadura em meios de Petragnani, Lowenstein-Jensen e LowensteinJensen com antibióticos (Penicilina Ge Ácido nalidíxico). Houve diferença entre os percentuais de recuperação de micobactérias a partir das fezes de suínos $(\mathrm{p}<0,05)$ e o método ácido com ressuspensão em solução de anfotericina $\mathrm{B}$ e semeadura em meio de Lowenstein-Jensen com antibióticos apresentou os melhores resultados ( $87 \%$ de recuperação de micobactérias).

Palavras-chave: Mycobacterium avium, isolamento, fezes, suínos

\section{REFERENCES}

1. Acland, H.M.; Whitlock, R.H. (1986) Mycobacterium avium serotype 4 infection of swine: the attempted transmission by contact and the sequence of morphological changes in inoculated pigs, $J$. Comp. Path., 96: 246-266.

2. Balian, S.C.; Ribeiro, P.; Vasconcellos, S.A.; Pinheiro, S.R.; Ferreira Neto, J.S.; Xavier, J.G.; Morais, Z.M.; Telles, M.A.S. (1997) Linfadenites tuberculóides em suínos abatidos no estado de São Paulo, 
Brasil: aspectos macroscópicos, histopatológicos e pesquisa de micobactéria. Rev. Saúde Pública, 31(4): 01-10.

3. Balian, S.C.; Pinheiro, S.R.; Guerra, J.L.; Morais, Z.M.; Ferreira, F.; Ferreira Neto, J.S. (2002). Estudo comparativo de dois métodos de descontaminação na pesquisa de micobactérias. Arq. Inst. Biol., São Paulo, 69(2): 11-14.

4. Centro Panamericano de Zoonosis. Bacteriologia de la tuberculosis humana y animal. Ramos Mejia, Buenos Aires: 1979. 63p. (Serie de monografias cientificas y tecnicas, C.P.Z., 11).

5. Centro Panamericano de Zoonosis. Métodos de laboratório de microbiologia veterinária para el aislamento e identificacion de micobacterias. Ramos Mejia, Buenos Aires: 1973. 60p. (Série de Monografias Científicas y Tecnicas, C.P.Z., 6).

6. Corner, L.A.; Trajstman, A.C.; Lund, K. (1995). Determination of the optimum concentration of decontaminantss for the primary isolation of Mycobacterium bovis, New Zealand Vet. J., 43: 129133.

7. David, H.; Brum, L.; Prieto, E. (1994). Manual de Micobacteriologia em Saúde Pública. Princípios e Métodos. Lisboa: Inst. Hig. Med. Trop.

8. Dey, B.P.; Parham, G.L. (1993). Incidence and economics of tuberculosis in swine slaughtered from 1976 to 1988. J. Am. Vet. Méd. Assoc., 203(4): 516-519.

9. Fundação Nacional de Saúde (Brasil). (1994). Centro de Referência Professor Hélio Fraga. Manual de bacteriologia da tuberculose. $2^{\mathrm{a}}$. ed. Rio de Janeiro: FNS, 115p.

10. Janetschke, P. (1963). Uber die tuberkulose bein schwein. Monatshefte Veterinar Medizin, 18(20): 800.

12. Jorgensen, J.B. (1982). An improved médium for culture of Mycobacterium paratuberculosis from bovine faeces. Acta Vet. Scand., 23(3), 325-335.

13. Koneman, E.W. (2001). Diagnóstico microbiológico: texto e Atlas colorido. $5^{\mathrm{a}}$ edição - São Paulo. MEDSI Editora Médica e Científica. $1465 \mathrm{p}$.

14. Martins, L.S. (2001). Epidemiologia e controle das micobacterioses em suínos no Sul do Brasil: estimativa do impacto econômico e estudo da sazonalidade. São Paulo, 151 p. (Master. Epidemiologia Experimental e Aplicada às Zoonoses - Faculdade de Medicina Veterinária e Zootecnia - USP).

15. Morés, N.; Silva, V.S.; Ventura, L.V. Linfadenite granulomatosa em suínos causada por micobactérias atípicas. Embrapa suínos e aves, http://www.cnpsa.embrapa.br/?/artigos/2001/artigo-2001n008.html>.

16. Oliveira, E.M.D.; Morais, Z.M.; Tabata, R.; Dias, R.A.; Oliveira, R.S.; Leão, S.C.; Morés, N.; Guerra, J.L.; Vasconcellos, S.A.; Ferreira, F.; Pinheiro, S.R.; Balian, S.C.; Ferreira Neto, J.S. (2002). Avaliação da virulência de estirpes de Mycobacterium avium presentes na população de suínos no sul do Brasil. Braz. J. Vet. Res. Anim. Sci., 39(4): 202-207.

17. Pinheiro, S.R.; Vasconcellos, S.A.; Ito, F.H.; Ferreira Neto, J.S.; Morais, Z.M. (1992). Influência da matéria orgânica na atividade micobactericida de cinco desinfetantes de uso pecuário. Braz. J. Vet. Res. Anim. Sci., 29(1): 51-60.

18. Román, M.C. (1990). Microbiologia clinica de las enfermidades por micobactérias (tuberculosis, lepra e micobacteriosis). Universidade de Cordoba - Facultad de Medicina, Espanha. 29-30.

19. Silva, V.S.; Morés, N.; Dutra, V.D.; Ferreira Neto, J.S.; Saad, M.H.F. (2000). Estudo da transmissão horizontal de Mycobacterium aviumintracellulare em suínos. Arq. Bras. Méd. Vet. e Zootec., 52(60). http://www.scielo.br/cgibin/fppe/fbtext?got=last\&pid=S010209352 000000600002\&lng.

20. Sircilli, M.P.; Oliveira, R.S.; Balian, S.C.; Ferreira, F.; Ferreira Neto, J.S.; Silva, V.S.; Morés, N.; Chimara, E.; Leão, S.C. (1999). Epidemiologia e controle das micobacterioses suínas no sul do Brasil. Estudo molecular dos isolados: identificação dos agentes presentes nas lesões (resultados preliminares). IX Congresso Brasileiro de Veterinários Especialistas em Suínos, Belo Horizonte, p. 221-222.

21. Szazados, I. (1993). Àz atípuzos mycobacteriumkkal (Mycobacterium avium) fertõzöttsertéshús fogyasztásának egészségügyi kockázatáról. [ Health hazards of pig meat with atypical mycobacterial infection (Mycobacterium avium)]. Magyar - Ammatorvosok - lapja, 48(3):170-171 